\title{
Constructing the Global Diversity or Reproducing the Orientalist Gaze: Evaluating Identity Options and Cultural Elements in an English Intercultural Communication Textbook
}

\author{
Yu Zhang ${ }^{1}$, Zhijuan $\mathrm{Ni}^{1}$, Juan Dong ${ }^{2} \& \mathrm{Jia} \mathrm{Li}^{1}$ \\ ${ }^{1}$ School of Foreign Languages, Yunnan University, Kunming, China \\ ${ }^{2}$ School of Foreign Languages, Southeast University, Nanjing, China \\ Correspondence: Yu Zhang, School of Foreign Languages, Yunnan University, Chengong Campus, Kunming, \\ 650504, China.
}

Received: November 11, 2021

Accepted: December 17, 2021

Online Published: December 27, 2021

doi: $10.5539 /$ elt.v15n1p130

URL: https://doi.org/10.5539/elt.v15n1p130

\begin{abstract}
English is often ideologically constructed as a global language to facilitate intercultural communication between people of diverse cultural backgrounds. However, it still remains unknown to what extent English learning can enhance English learners' awareness of global diversity. Given the dominant population of English learners in China, it is of great significance to investigate how English learning might facilitate Chinese learners' global vision and cultivate their intercultural competence. Seeing language textbooks as a key site of cultural and linguistic representation, this study scrutinizes the hidden ideologies discursively constructed in an English Intercultural Communication (EIC) textbook targeting Chinese English learners. Data are collected from dialogues, case studies, reading passages, cultural notes, exercises in the textbook. Informed by concepts of orientalism and banal nationalism, the study reveals that the distribution of characters is nation-based, essentialized, and even stigmatized. There is an inconsistency between the discursive construction of English as a global language and the actual representation of USA/UK-centered ideology. Chinese and other non-English learners are linguistically and culturally subjected to orientalist interpretation. The internal orientalist representation of Chinese speakers is also reproduced within the diverse backgrounds of Chinese population. Based on the findings, we argue that the simplified, unbalanced and unequal representations of cultural elements may hinder English learners' awareness of cultural diversity. The study suggests that a more diversified representation of cultural practices should be adopted in EIC textbooks to cultivate the global citizenship through English language education.
\end{abstract}

Keywords: identity options, cultural representation, English intercultural communication textbook, orientalism, banal nationalism

\section{Introduction}

Previous studies have confirmed the strong influence of English language teaching (ELT) textbooks on the cultivation of talents proficient in English, conversant with World cultures, and adept at intercultural communication (Apple, 1990; Byram, 1997; Cunningsworth, 1995; Cortazzi \& Jin, 1999; Li, 2017). Many scholars also argue that ELT textbooks as ideological artefacts, the cultural contents embedded in them will shape learners' identities and influence learners' impression towards different cultures (Apple, 1990; Awayed-Bishara, 2015; Setyono \& Widodo, 2019; Rashidi \& Safari, 2015). Simultaneously, the important role of textbooks stimulates questions about whose culture is needed to be addressed to students in what context by which means (McDonough, 2002; Piller, 2017) in that the decision to include and exclude certain culture in textbooks contains some political identities (Curdt-Christiansen \& Weninger, 2015), power relations (Clifford, 1986), and hidden agenda (Tajeddin \& Teimournezhad, 2015).

Considering the mediating role of ELT textbooks, numerous general ELT textbooks used for cultivating students' ability of listening, speaking, reading and writing also introduce some cultural elements (Hu \& Gao, 1997). Meanwhile, specialized English Intercultural Communication (EIC) textbooks are going burgeoning development (Harms, 1973; Rich, 1974). 
As the rise of culture-loaded ELT textbooks, a number of scholars have attempted to reveal the cultural representation in these textbooks. They find that there exist many problematic representations, featured with misrepresentation, over-generalization or essentialization, and biased representation (Alshammri, 2017; Chang, Holt, \& Luo, 2006; Li, Ni, \& Dong, 2020). However, most of these studies center on general ELT textbooks, while to our best knowledge, studies on what and how cultural elements constructed in EIC textbooks are relatively few.

Given the backdrop mentioned above, with content analysis, this study scrutinizes an EIC textbook targeting Chinese English learners to investigate what identity options and cultural elements are presented, what emerging themes are generated, and what ideologies are discursively reproduced. This study will offer a nuanced account of the under-researched intersection of identity options and cultural representations in EIC textbooks and shed some light on textbook compilation.

\section{China's Embracive Discourse of Using English to Include Diversity as Research Context}

With the growth of China's comprehensive national strength, China is actively integrating itself deeper into the world system with a positive stance of all-round opening up across the board. Driven by such a trend, English education in China has also transited from "a context of liberation to one of globalization" (Zheng \& Davison, 2008). The status of English education in China fluctuates with China's policy, economic interests and other socio-political factors, but the policy of opening up in 1979 can be counted as a rough critical point at which Chinese people's attitude towards English varies from refusal, passive acceptance, to active learning it as a tool to link China with the whole world (Pan, 2017). Since opening up, a large number of intercultural communication talents have been urgently needed in accordance with China's full integration into globalization, which impels China's education reform. Therefore, the constantly updated English language curriculum attaches high importance to enhance learners' capacity to use English for communication and cultural awareness enhancement. Many ELT textbooks are also published in response to the needs of the country.

Although students are inundated with materials aiming to improve cultural awareness, there exist many discrepancies between discourse and practice (Chang, Holt, \& Luo, 2006; Duan, 2020; Lee, 2010; Piller, 2007). In other words, the goal runs counter to the reality for the reason that intercultural communication in nowadays is not limited to a certain group or country, whereas educational institutions continue to reproduce existing stereotypes and social hierarchies by erasing the diversified attributes of "real people" and presenting contents of the dominant culture (Lee, 2010; Piller, 2007). In Chang, Holt, \& Luo's (2010) paper, turning the traditional Eurocentric perspective into Asaincetric perspective, they examined how East Asians were represented in two world-renowned EIC textbooks. Their findings showed that Asians were always written on specific places for seeing. They were grouped by nationality and ethnicity. Consequently, stereotypes like Asians cherishing collectivism, social harmony and hierarchy were regenerated. However, the over-generalized representation of East Asian in these two EIC textbooks was inconsistent with learners' real life experience and actual situation. Even worse, such phenomenon is ubiquitous in EIC literature (Piller, 2007).

Therefore, following previous studies' inquiry (Chang, Holt, \& Luo, 2006; Duan, 2020), with the purpose of offering some understanding for future teaching material compilation in line with the needs of EIC talent development, this study turns the research object into an EIC textbook distributed in China to explore the cultural representation and hidden ideologies embedded in it with the following research questions:

1) What are identity options and cultural elements relevant to the World and China represented in the EIC textbook?

2) How are ideologies discursively reproduced by the identity options and cultural elements embedded in the EIC textbook?

We employ concepts of orientalism and banal nationalism to answer these questions and use content analysis for coping with the data and finding out the emerging themes. Before introducing the two concepts and rationalizing the methodology we choose, we would like to give an elaborated literature review relating to representations of identity options and cultural elements in ELT textbooks.

\section{Literature Review}

\subsection{Conceptualizing Textbooks}

Textbooks are regarded as fundamental and even unquestionable truth by students. According to Dendrinos (1992, p. 131), "the textbook is considered by both the students and teachers who use it as the authority which determines what is to be learned and how". Through presenting ideologically constructed reality, textbooks neutralize and naturalize certain types of knowledge (Tajeddin \& Teimournezhad, 2015) and construct some 
imagined identities by and in discourses (Shardakova \& Pavlenko, 2004). Nevertheless, there is no neutral schooling for education always aims to serve the interests of certain groups' domination over others by introducing certain ideologies and social powers (Tajima, 2011).

ELT textbooks are also not free from ideologies by in favor of certain groups of people who are dominant. Ostensibly, they are "entry points to new cultural realities" (Liddicoat \& Scarino, 2013, p. 84). But in fact, as a kind of ideology (Apple, 1990) and hidden curriculum (Cunningsworth, 1995), they are "cultural products" which infuse "identities, assumptions, and worldviews of their creators and their intended audience" (Liddicoat \& Scarino, 2013, p. 84). They legitimize specific types of knowledge (Haynor, Apple, \& Christian-Smith, 1992) and determine whose culture is taught in classroom (Ilieva, 2000).

EIC textbooks, a specific kind of ELT textbooks, are particularly susceptible to problems caused by struggles over power and ideology (Van Dijk, 1992). They are an authoritative mechanism "esentializing difference through uncritical acceptance of dualism, reproducing prejudices and stereotypes through discursive imperialism" (Chuang, 2003, p. 224).

\subsection{Research on ELT Textbooks}

Since the rise of intercultural communication, cultural teaching has become an indispensable part of language education (Byram, 1997; Hinkel, 1999). Many scholars have made continuous research to explore the cultural content of textbooks with several critical issues relating to cultural contents and pedagogical issues (Ilieva, 2000; Alshammri, 2017; Li, Duan, Dong, \& Sharif, 2019), cultural politics and ideologies (Shardakova \& Pavienko, 2004; Taki, 2008; Tajeddin \& Teimournezhad, 2015); intercultural communication literature advice (Cortazzi \& Jin, 1999; Piller, 2017).

Through an examination of current ELT literature, the textbooks that scholars chose to investigate cultural representation were mainly focused on general ELT textbooks or specific EIC textbooks. On studies of general ELT textbooks, researchers scrutinized the cultural content of textbooks distributed in different countries for students at different levels from different perspectives successively and maturely. Table 1 summarizes recent studies that have investigated the cultural representations of general ELT textbooks.

Table 1. Summary of some studies on ELT textbooks

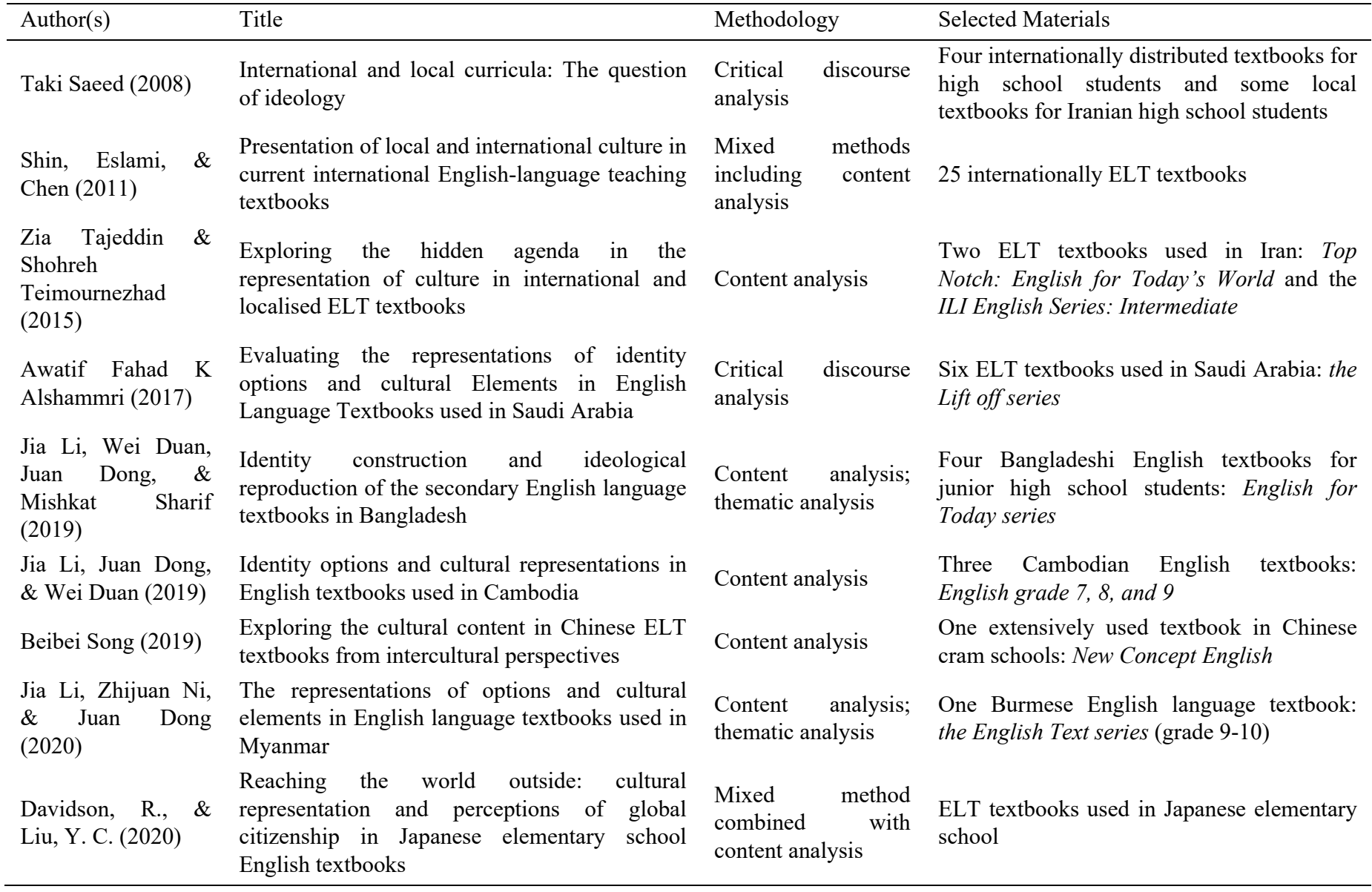


From this table, it is clear that content analysis and critical discourse analysis are widely used. Adopting these methods, scholars found that current ELT textbooks existed problematic cultural representation touching upon some hidden curriculum (Shin, Eslami, \& Chen, 2011; Taki, 2008). For example, with content analysis, Shin, Eslami and Chen (2011) showed that the cultural representation still remained the traditional-oriented knowledge and inner circle culture dominated in seven series of internationally distributed ELT textbooks. Similarly, Taki (2008) explored four internationally distributed textbooks for Iranian high school students with critical discourse analysis and found that these textbooks conveyed the discourse of Western-dominated economic framework.

Furthermore, many researchers also explored how identity was constructed in language textbooks although it formed a relatively new direction of research (Alshammari, 2017; Norton, 2000). Alshammari (2017) argued that two clearly delineated imagined communities were constructed in six books from the Lift off series targeting Saudi Arabian learners. The representation of characters appeared a Saudi-centric orientation, while foreign characters were oversimplified and misrepresented. Similarly, Li, Ni and Dong's latest study (2020) found that English textbooks published by the union of Myanmar Ministry of Education covered more Myanmar people and the gender-biased representation of males and females was quite noticeable. Myanmar female characters were confined to family domains whereas male characters had more decent occupation options.

On the aspect of research perspective, Song (2019) explored the cultural content in New Concept English used in Chinese cram schools and analyzed its strength and weakness of its cultural content from intercultural perspective. Grounding the finding that the target culture was significantly ignored in stark contrast with the general culture and the source culture, the author proposed that textbooks should incorporated both the source culture and the target culture to increase students' intercultural awareness. From a sociocultural perspective, Shin, Eslami and Chen's investigation (2011) also highlighted the importance of equal distribution of source and foreign cultures in enhancing intercultural competence.

However, compared with studies on general ELT textbooks, research on specific EIC textbooks were relatively few and superficial. For instance, taking references in 8 intercultural communication textbooks compiled by Chinese scholars for English majors as research objects, Chi (2010) used computer aided system to sort out the data and found that the literature of these IC textbooks mainly focused on China and the United States. Suo (2013) used content analysis to analyze covers, catalogues, prefaces and postscripts of 105 IC textbooks commonly used in China. Then cooperating with Weng and Gu, he (2015) expanded his samples to 122 IC textbooks and made an analytical assessment of 30 years of intercultural communication materials in China with the same method. Both studies found that the current intercultural communication textbooks in China had some drawbacks which hindered the cultivation of intercultural communication talents. Chang, Holt and Luo (2006) chose two representatives of EIC textbooks to examine how East Asians were represented and found that using nation as base, Asian characters were oversimplified and misrepresented.

Although these studies have set forth how cultural elements and identities are structured in textbooks with vast samples and revealed the existing deficiencies of current textbooks for training intercultural communication talents, most of them are theoretically and practically inadequate (eg. Chi, 2010; Suo, 2013; Suo et al., 2015). Theoretically, their approach to textbook evaluation is largely descriptive, lack of a deep-down and holistic view of the ways how source culture and foreign culture are represented in IC textbooks and what identities and ideologies are shaped by such representation. Practically, they ignores the diversity of culture and identity, thus, putting forward nation-based intercultural communication advice again.

Therefore, in order to provide a specific picture about the cultural representation in EIC textbooks and contribute to the existing literature about language and culture teaching, this study scrutinizes meticulously identity options and other cultural elements constructed in one representative EIC textbook published in China.

\section{Theoretical Framework}

\subsection{Orientalism}

This study is largely informed by Said's $(1978,2003)$ critique of Orientalism which highlights the power-knowledge relations articulated in the interests of the power of the West. This form of exerting power over the Orient is mainly achieved by "making statements about [them], authorizing views of [them], describing [them], by teaching [them], settling [their lands], ruling over [them]" (Said, 1978: 3). In order to maintain its hegemony over the Orient, the Occidental persists in "disregarding, essentializing, denuding the humanity of another culture, people, or geographical region" and regards the Orient as something that is "not only displayed but has remained fixed in time and place for the West" (Said, 2003, pp. 108-109). 
One tenet contributing the wide circulation of the ideology of the dominance of the West is "material (and institutional) presence to show for itself" (Said, 2003, p. 273). In addition to displaying real bodies and people as specimens of the "exotic" cultural others, paintings, books and newspapers equally contributes to the exoticisation of Other (Piller, 2007). For example, Chinese people are often portrayed as the "exotic" touristified Other and faceless masses under the consumption of the West in newspapers (Chen, 2013).

However, Orientalist representations are not simply an autonomous creation of the West, but the Orient "participates in its owner Orientalising" through local materials (Said, 2003). Following this inquiry, Arif Dirlik (1996) proposed the concept of "self-Orientalism" or "the Orientalism of the Orientals". The representation of incompetent and demonized female images represented in Chinese textbooks for international students emanated by China is a case in point (Duan, 2020). Then, with the same logic, the concept of Orientalism is extended to "internal Orientalism" to refer to the cosmopolitan Chinese's fascination to "exotic" minority cultures which are labeled as backward and subordinated icons (Schein, 1997).

\subsection{Banal Nationalism}

As mentioned above, a key factor contributing to Orientalism is essentialism which is also an important form of banal nationalism aiming "to cover the ideological habits which enable the established nations of the West to be reproduced" (Billig, 1995, p. 6). Derived from Michael Billig's 1995 book of the Banal Nationalism, the ideological term is widely used in academic discussion of how national stereotypes are created, recreated, and reinforced with the formation of national identity and cultural affiliation in mundane, unnoticeable but pervasive ways in intercultural communication settings (Piller, 2017). One emblematic mindset of banal nationalism is the association of one language and one culture with one nation, for instance, "the Chinese language" onto "Chinese culture" onto "China". The straightforward mode of "language X-culture X-nation X" relationship naturalizes why a particular language (variety) and culture receives dominance whilst other languages (varieties) and cultures are marginalized since schooling socializes us into national accessories (Piller, 2017; Li, 2020).

Ostensibly, this one-on-one match seems rational, but it does reduce individuals to mono-dimensional discourses in which the kaleidoscopic traits of human beings as individuals are away from visibility. When these "essentialized groups" encounter each other in intercultural communication literature, nation-based stereotypes and nation-based intercultural communication advice cannot be immune from it. However, in the multicultural and mobile world, the static and decontextualized approach towards intercultural communication will undoubtedly reproduce national prejudices, limiting the smoothness and effectiveness of intercultural communication (Li \& Han, 2020). For example, Han's (2011) study exemplifies that the ubiquitous banal nationalism permeating into daily life in Canada excludes Chinese immigrants from the mainstream society, so that Chinese are frustrated while conducting intercultural communication with Canadians (as cited in Li \& Han, 2020).

In this study, we just focus on the authoritative schooling materials - one EIC textbook used in China to investigate what identities and cultural elements of the World and China are represented and what ideological consequences are created.

\section{Methodology}

\subsection{Data Selection and Description}

To provide a case study, the research sample in this study just revolves around the cultural elements in one EIC textbook published in China, English Intercultural Communication Course in College.

The following reasons make the textbook eligible, representative and meaningful for study. First, its authority of publication can provide qualified and professional learning resources. The textbook is a national planning textbook for undergraduate higher education during the Twelfth Five-year Plan period, led by the Ministry of Education of the People's Republic of China (Yan, 2015). It was published by Tsinghua University Press in 2009 and the second edition was issued in 2015 (Yan, 2015). Second, the extensive application makes it representative for research. The textbook is widely adopted as a teaching and learning material for comprehensive intercultural communication teachers and learners and becomes the main textbook for the National Excellent Course of College English Intercultural Communication in a Chinese university (Yan, 2015). Thirdly, its rich contents and writing purposes make this research meaningful. Guided by the document College English Curriculum Requirements (2007), the textbook integrates language, culture and intercultural communication into it, which greatly contributes to boasting learners' intercultural communication competence (Yan, 2015). 


\subsection{Data Collection and Analysis}

Data are collected from dialogues, case studies, reading passages, cultural notes, exercises and images in the textbook. Following previous studies on language textbooks (Shardakova \& Pavlenko, 2004; Taki, 2008; Alshammri, 2017; Li et al., 2019, 2020), the calculation of identity options is based on the number of the representation in gender, occupation, and nationality. If the same character appears more than once, it will be counted once only.

Regarding the data analyzing method, content analysis is adopted to quantify these qualitative data objectively and systematically (Krippendorff, 2013) and to explore the representation of different cultural groups (Shardakova \& Pavlenko, 2004), thereby detecting whether intercultural communication is limited in certain groups. The strength of content analysis is that it allows researchers to identify general themes first and then specific themes can be generalized after interactively data coding and in-depth analysis. Aligned with previous scholars using content analysis explicitly and implicitly to analyze the emerging themes embodied in language textbooks (Alshammri, 2017; Duan, 2020; Li, Dong, \& Duan, 2019), we attempt to find out patterns emerging from the data collected from English Intercultural Communication Course in College. In our research, we have identified the recurring patterns that are salient in terms of their frequency of occurrence and their relevance to identity options and other cultural representation. These patterns can be summarized as "stigmatized \& stereotyped the Orient culture", "nation-based identity options and cultural practices", "Anglophone-centric perspectives as global supremacy", "over-generalized non-western cultures", and "internal uneven representation between Han Chinese \& other ethnic minorities". With the same way, thematic relationships are also developed and categorized as shown below.

\section{Findings and Discussion}

\subsection{Stigmatized \& Stereotyped the Orient Culture}

Similar to the previous study (Chen, 2013) conducted in English materials in which the Orient are portrayed as the "exotic" cultural Others, the textbook also uses self-made or cited claims conforming to the Western stereotyped gaze of the Orient such as "passive Oriental people, the despotic leader, and the uncaring Communist government" (Pennycook, 2002, p. 172), thus, trapped into Orientalism (Said, 2003) or self-Orientalism (Said, 2003; Dirik, 1996).

\subsubsection{The Silent, Submissive, Roundabout and Timeless Orient}

In this textbook, the Oriental is discursively constructed as silent, submissive, roundabout, and timeless through demonstration of cultural theory models proposed by Western scholars. For example, in chapter seven Cultural Patterns, the textbook cites Edward T. Hall's "Context-Culture Theory"; Kluckhohn and Strodtbeck's "Value Orientation", Geert Hofstede's "Dimensions of Cultural Variability" to support the Oriental characteristics put forward by the Occidental.

Case studies also contribute to reinforcing the image of the Oriental in the eyes of the Occidental as silent, submissive, roundabout and timeless. In case 12 "Why Don't You Eat the Pizza?" (pp. 61-62), for example, the Malaysian student is depicted as inexplicably silent, submissive, adhering to traditions irrespective of the modernization drive.

In this case, the American student Kenneth handed one pizza to the Malaysian student Vernon with his left hand. Although Vernon was offended, he still took that pizza and put it on his plate without eating it. Kenneth was confused about Vernon's reaction and asked Vernon "Are you all right?" Instead of telling Kenneth that his actions touched Malaysian cultural taboos, Vernon said "I'm fine". Then when Kenneth continued to ask the reason why he didn't eat the pizza, Vernon kept silent. Kenneth was again lost in confusion.

Kenneth offended Vernon, but Vernon did not point out it, which might be out of friendliness or the consideration of guiding learners to understand Malaysian cultures. However, in intercultural communication context, the reiteration of Vernon' silence confusing the American student might suggest that Vernon seems incapable of expressing his opinion and what he can do is just to accept. The image of Vernon is shaped as 'exotic' silent, roundabout, effeminate and submissive.

The picture provided also shapes the image of Vernon as submissive and timeless. In this picture, the American student was taller, stood straight and looked down at the Malaysian student with a haughty countenance, while the Malaysian student was thinner and shorter. He leaned forward, bit his lip, clenched his fists and glanced up at the American student. The size, manner, eyesight contrasts reproduce, to some extent, the image of the Orient as submissive. 


\section{Why Don't You Eat the Pizza?}

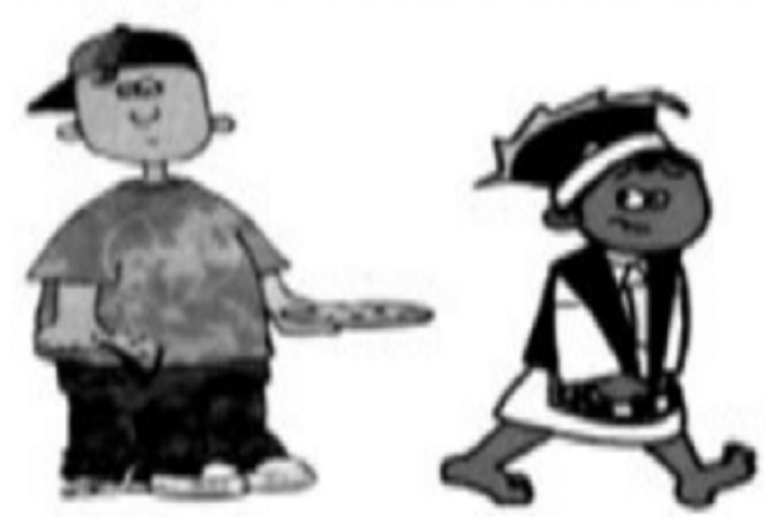

Figure 1. Why Don't You Eat the Pizza (p. 61)

Besides, the contrast of wearing between them reproduces the image of the Orient as the displayers of traditional costumes despite the encroachment of modernity. In the picture, the American student wore modern cloth and a hat at an angle, while the Malaysian student wore "exotic" costumes and no pants and shoes. Vernon was depicted as a cultural Other living his life undistributed by the influence of modernity.

\subsubsection{The Authoritarian, Corrupt and Mysterious Orient}

In addition to being presented as an index of passiveness, timelessness, the Oriental is also represented as the Other valuing autocracy, corruption and mystery. In the textbook, the image of the Orient other is carried out explicitly as follow.

Americans value achievement, Chinese value power, Westerners value self-direction, Asians value conformity. P. 213

Chinese business values emphasize kinship, interpersonal connections, respect for elders, and hierarchy. P. 252

Business contracts in China are often specified in legal terms but implemented relying on trust and relationships between the parties involve. P. 252

To do business in Saudi Arabia, you must have a sponsor act as an intermediary, make appointment, and arrange meetings. P. 256

Within many Asian and Asian American cultures, students and parents would not openly and directly question the authority statements of a teacher. P. 263

Many Asian Cultures also believe in the supernatural as an important source of illness. P. 268

By comparing the East and the West through binary opposition, the East is shaped as an image that puts individual will above the social system, stresses interpersonal connections (“关系”, "guanxi”) in mundane social practice, and attaches great importance to social hierarchy and supernatural powers.

In sum, such problematic approach of the inclusion of communication skills and cultural contents in the Intercultural Communication textbook fails to help learners build up cultural confidence and recognize diversified cultures critically.

\subsection{Nation-Based Identity Options and Cultural Practices}

Resembling many intercultural communication literature (Chang, Holt, \& Luo, 2006; Piller, 2017), this textbook also takes nation as the locus of cultural difference from a mono-dimensional and essentialist perspective. Purporting to regard individuals as members of a specific nation and a specific culture, intercultural communication falls naturally into banal nationalism (Billig, 1995). In this textbook, the judgment toward a certain people is elevated to the judgment toward a national group in that the most remarkable information about these characters is their nationality. They are generalized and essentialized into the iconic symbol of a specific nation. 
In English Intercultural Communication Course in College, there are 143 characters, of whom 119 are foreign characters and 24 are Chinese characters. Except gender, occupation, all information about them is their nationality as shown in Table 2.

Table 2. Nationality distribution in English Intercultural Communication Course in College

\begin{tabular}{|c|c|c|c|c|}
\hline & Nationality & Male & Female & Undefined \\
\hline \multirow[t]{6}{*}{ Europe } & Ukraine & - & 1 & - \\
\hline & France & - & - & 1 \\
\hline & Scotland & - & - & 1 \\
\hline & British & 6 & 1 & - \\
\hline & Denmark & - & 2 & - \\
\hline & German & 2 & 1 & - \\
\hline \multirow[t]{2}{*}{ Americas } & Canada & 1 & - & - \\
\hline & America (US) & 44 & 20 & 1 \\
\hline \multirow[t]{12}{*}{ Asia } & Chile & 1 & - & - \\
\hline & China & 11 & 12 & 1 \\
\hline & Japan & 4 & 3 & - \\
\hline & Korea & 4 & - & - \\
\hline & India & 1 & 1 & - \\
\hline & Thailand & 1 & 1 & - \\
\hline & The Philippines & 2 & 2 & - \\
\hline & Laos & 1 & - & - \\
\hline & Malaysia & 1 & - & - \\
\hline & Indonesia & 1 & 3 & - \\
\hline & Saudi Arabia & 3 & - & - \\
\hline & Turkey & - & 1 & - \\
\hline Africa & Africa & 3 & 2 & - \\
\hline \multirow[t]{2}{*}{ Oceania } & Australia & 1 & - & - \\
\hline & Tonga & - & 2 & - \\
\hline
\end{tabular}

Such nation-based identity construction creates, recreates and reinforces existing stereotypes by ignoring, if not erasing, different characters' kaleidoscopic backgrounds, which goes against the aim of developing learners' cultural awareness towards diversified cultures as the textbook purports.

In addition, the cultural representation of other foreigners also recreates nation-based stereotypes by essentializing personal attributes into national categories. For instance, in case 45 (pp. 241-242), the Turkish student Ira's extremely friendly behavior is attributed to Turkish culture. The formula "nation equals culture" reproduces stereotypes about all Turkish people who are so over warm-hearted that people fell suffocated. In order to verify the reliability of this stereotype, the textbook spurs students to interpret it with Hofsted' dimensions of cultures. However, Hofsted's theory regards cultures as static, thus reducing all cultures into six dimensions and categorize people in groups just according to their nationalities. It is, in essence, another typical source generating national stereotypes based on the "one nation-one culture' formula (Piller, 2007).

\subsection{Anglophone-Centric Perspectives as Global Supremacy}

A further feature of the representation of identity options and cultural elements in English Intercultural Communication Course in College reveals that Anglophone-centric perspectives are discursively reinforced as global supremacy through over-represented Western identities and culture and the positive depiction of the Western culture. The discursive construction of Anglophone-centric perspective as global supremacy in the textbook is per se the manifestation of Orientalism (Said, 1978, 2003). 
Except generating nation-based stereotypes, Table 2 also exemplifies a salient point that the representation of identity options is White Anglophone-centered. Although there are 119 foreign characters represented in the textbook, Americans and other White Anglophones take the biggest share. Anglophone countries are constructed as ideal interlocutors for intercultural communication. The Anglophone-leading character representation simplifies the diversity of cultures attached to characters, implying the dominant power of Western culture.

\subsubsection{Western Culture as Power}

Furthermore, a close examination of the representation of the World in the book reveals that Western culture is discursively constructed as power pursued by other countries. On page 82 , the textbook conveys that the norms of Western culture need to be followed by other countries.

The meanings people attach to their perceptions are greatly determined by their cultural background. For example, Western people like dogs, and they believe dogs are human's best friends. They love dogs as pets. In English, people say "lucky dog", but in Chinese we say “幸运儿”. In some countries, dogs are delicious food, such as in Korea. In 2002, the World Cup was held in Japan and Korea, and people argued whether to ban eating dogs in Korea at that time, because Western people believe dogs are friends, not food. P. 82

In this excerpt, Koreans argue whether to ban eating dogs during the World Cup held in Japan and South Korea for the reason that Western people like dogs and they believe dogs are human's best friends. Casting aside stereotypes, Koreans argue whether to ban eating dogs at that time is not out of animal protection, but because of eating dogs violates the norms of Western culture. Western culture means power and market and other cultures need to constantly adjust to accommodate the gaze of westerners on a moral vantage point.

\subsubsection{Western Culture as Civilization}

Apart from describing Western culture as power, Western culture is also regarded as civilization in the textbook. One of the best manifestation of constructing Western culture as civilization is the presentation of Rudyard Kipling's widely-read poem "We and They" in Case 13 (p. 65).

\begin{tabular}{|c|c|}
\hline \multicolumn{2}{|c|}{$\begin{array}{l}\text { We and They } \\
\quad \text { - Rudyard Kipling }\end{array}$} \\
\hline $\begin{array}{l}\text { Father, Mother, and Me, } \\
\text { Sister and Auntie say } \\
\text { All the people like us are We, } \\
\text { And everyone else is They. } \\
\text { And They live over the sea } \\
\text { While we live over the way, } \\
\text { But-would you believe it? } \\
\text { - They look upon We } \\
\text { As only a sort of They! } \\
\text { We eat pork and beef } \\
\text { With cow-horn-handled knives. } \\
\text { They who gobble Their rice off a leaf } \\
\text { Are horrified out of Their lives; } \\
\text { While They who live up a tree, } \\
\text { Feast on grubs and clay, } \\
\text { (Isn't it scandalous?) } \\
\text { look upon We } \\
\text { As a simple disgusting They! } \\
\text { We eat kitcheny food. }\end{array}$ & $\begin{array}{l}\text { We have doors that latch. } \\
\text { They drink milk and blood } \\
\text { Under an open thatch. We have } \\
\text { doctors to fee. } \\
\text { They have Wizards to pay. } \\
\text { And (impudent heathen!) They } \\
\text { look upon We } \\
\text { As a quite impossible They! } \\
\text { All good people agree, } \\
\text { And all good people say, } \\
\text { All nice people, like us, are We } \\
\text { And everyone else is They: } \\
\text { But if you cross over } \\
\text { the sea, } \\
\text { Instead of over the way, } \\
\text { You may end by (think of it!) } \\
\text { looking on We } \\
\text { As only a sort of They! }\end{array}$ \\
\hline
\end{tabular}

Figure 2. We and They (p. 65)

"We and They" is yet an example of a large body of discourse in which the superiority of western culture is esteemed as civilization different from those exotic Other. (McClintock, 1995). It contains the idea that the Westerners assume the sacred mission of civilizing the Other. At first glance, this poem seems to teach us to think in others' shoes and don't judge others arbitrarily from the last several lines. But after reading closely, the poem creates a division between the civilized "We" and the barbaric "They". It units Americans as an in-group "We", but also creates an out-group made up of all non-Americans as "They". The life of "We" is decent, reasonable and moral-guided. "All people like us are we", while the other are barbaric, gobbling rice off a leaf, living up a tree, drinking milk and blood under an open thatch, and seeing a wizard. When people read such a 
poem belonging to "We", he or she might feel a sense of superiority, while others will feel they are being challenged and want to pursuit the civilized "We" naturally.

\subsubsection{USA-Centered Ideology}

Moreover, the global Western supremacy is entrenched by Americanized culture (Pillipson, 2008). In this textbook, Although English is constructed as a global English, the United States is essentialized as the representative of Western culture in mundane social practices. All fields of international communication, business and education use USA as a reference.

As for intercultural communication, the textbook places a high premium on Western communication style especially marked by American styles with many direct statements such as "our discussion of communication often reflects a Western orientation" (p. 46); "Business communication books come mainly from Western cultures, particularly the United States. Accordingly, the authors tend to emphasize the things that are important in business communication in the United States" (p. 158).

In the educational context, the United States is once again shaped as an ideal destination for studying abroad. Students in the case studies all flocked to the United States to study.

Vernon, a student who recently arrived in America from Malaysia. (case 12)

Olga, a Ukrainian exchange student studies at the same college as Jim in the United States. (case 14)

Akira and Michiko are Japanese overseas students in the USA. (case 18)

Zhu Xiaohua was a Chinese student who came to the USA, just two months ago. (case 38)

In a university program where there were both Chinese and American students. (case 42)

Wu Lian, an English major studying at a university in the USA, starts out confidently. (case 52)

\subsection{Over-Generalized Non-Western Cultures}

As indicated by Table 2 , there is an extremely asymmetric cultural representation between foreign culture and Chinese culture, between western culture and non-western culture. The textbook nearly covers all aspects of Western culture, including literature, philosophy, festivals, arts, food, national history, and national geography (e.g. Civil War; Liberalism; Individualism; Emerson; Hippies; Hamburg; Coca-Cola; IBM...). Most of these cultural contents are even explained both in English and Chinese. However, when it comes to presenting non-western culture, the content is sparse and limited. For example, Chinese culture is only presented in these four categories: philosophy, festivals, food, and arts.

In terms of philosophy, only six maxims reflecting Confucianism and Taoism are presented in English without any interpretation. These thoughts have great influence on shaping the disposition of Chinese people. However, the lack of any explanation for these maxims is not conducive to learners' understanding of Chinese civilization, nor is it conducive to mutual learning among civilizations.

We should not measure other people's corn with our own bushel. _ Chinese saying P. 67

You cannot speak of oceans to a well frog, the creature of a narrow sphere. You cannot speak of ice to a summer insect, the creature of a season. C Chang Tzu P. 104

Those who know do not talk. Those who talk do not know. _L Lao Zi P. 166

Human beings draw close to one another by their common nature, but habits and customs keep them apart. Confucius P. 202

The gentleman pursues harmony instead of homogeneity; the vulgar man seeks uniformity at the sacrifice of harmony. Confucius P. 277

Do not do to others what you would not like them to do to you. _Confucius P. 328

As for festivals, the whole textbook just introduces “中秋节” (the Mid-Autumn Festival) in pre-reading task in the form of role play. The same is true of the presentation of Chinese food and arts, only using one proverb, two cultural notes, and one picture to illustrate them.

Furthermore, although the textbook appears some South and Southeast Asian cultures, such as the introduction of Indian Sari, Indonesian batik, Thai way of greeting-Sawadii-ka (Wai), these cultural elements are only some superficial etiquette devoid of the authentic and specific communication context. 
In sum, the representation of non-western cultural elements in the textbook is superficial and the diversity of world culture is simplified

\subsection{Internal Uneven Representation between Han Chinese \& Other Ethnic Minorities}

One of the main findings of this study indicates that "internal Orientalism" (Schein, 1997) is reproduced in the underrepresented Chinese culture by positioning Han culture and other minority cultures unevenly. Although 56 ethnic groups in China are recognized by legislation, Han culture is overwhelmingly deemed as an iconic token representing the national culture as represented in the textbook (Duan, 2020). Taking festivals as an example, the textbook only presents Mid-Autumn festival, originated from the Han Chinese but rarely practiced by some Chinese minority groups (Hong \& He, 2015), as the symbol of Chinese culture and lets students assume different nationalities to talk about their feelings towards the traditional Chinese Mid-Autumn Day, whilst festivals of other Chinese minority groups, such as the Water-splashing festival, the Torch festival and Nadam, are lost in visibility. Han culture is naturally constructed as an ideological token symbolizing the Chinese nation.

Our findings shows that EIC textbooks in China suffer the same problem as previous studies showed that Chinese textbooks unevenly constructs Chinese and ethnic cultures (Duan, 2020; Hong \& He, 2015). Therefore, it is argued that English Intercultural Communication Course in College exposes students in culturally-homogeneous and Han-culture dominated context, which runs counter to the principle of equality among all ethnic groups in China and is not good at guiding learners to realize their cultural heritage and social identity, thus impeding the improvement of their intercultural competence.

\section{Conclusion}

This study contributes a nuanced understanding of EIC textbooks published in China as well as the overall picture of current English teaching materials by scrutinizing the cultural elements in English Intercultural Communication Course in College, a textbook of China's 12th Five-Year Plan. Following the theory of orientalism and banal nationalism, the study demonstrates that this EIC textbook puts foreign cultures under the gaze of Westerners, sustains Nation-based stereotypical spectacles, reinforces Anglophone-centric perspectives as global supremacy, and reproduces internal uneven cultural representation between Han Chinese and other ethnic minorities.

Given these findings, some pedagogical implications are suggested to textbook writers, teachers and students respectively. Textbook writers should incorporate learners' diverse racial and cultural backgrounds to empower them to identify different voices and perspectives. Teachers should act as a cultural mediator to help students become cultural brokers in intercultural communication. Students should play their own agencies to reflect dynamic and diverse cultural practices critically.

However, as many studies, this study is not free from limitations. Firstly, the textbook analysis is only based on data relevant to research questions, which means some linguistic representations are leaved out. For a more in-depth study for future, linguistic representations should be covered. Secondly, this study only focuses one EIC textbook for China's 12th Five-Year plan. However, there are many other EIC textbooks targeting different groups at different levels. Therefore, future study can explore more intercultural communication textbooks belonging to the 12th, 13th and the forthcoming 14th Five-Year Plan textbooks so as to achieve a holistic and systematic understanding of EIC textbooks in China.

\section{References}

Alshammri, A. (2017). Evaluating the representations of identity options and cultural elements on English language textbooks used in Saudi Arabia. Master. Dissertation, Macquaire University, Australia.

Apple, M. W. (1990). Ideology and curriculum (2nd ed.). London: Routledge.

Awayed-Bishara, M. (2015). Analyzing the Cultural Content of Materials Used for Teaching English to High School Speakers of Arabic in Israel. Discourse and Society, 26(5), 517-542. https://doi.org/10.1177/0957926515581154

Billig, M. (1995). Banal Nationalism. London: Sage.

Byram, M. (1997). Teaching and assessing intercultural communicative competence. Clevedon: Multilingual Matters.

Chang, H. C., Holt, R., \& Luo, L. (2006). Representing East Asians in intercultural communication textbooks: A select review. The Review of Communication, 6(4), 312-328. https://doi.org/10.1080/15358590601014604 
Chen, X. X. (2013). Opening China to the Tourist Gaze: Representations of Chinese People and Languages in Newspaper Travel Writing since the 1980s. Ph.D. Dissertation, Macquarie University, Sydney, Australia.

Chi, R. B. (2010). A content analysis of references contained in intercultural communication textbooks for English majors in China. Foreign Language Education in China, 3(2), 70-74.

Chuang, R. (2003). A postmodern critique of cross-cultural and intercultural communication research. In W. J. Starosta \& G. M. Chen (Eds.), Ferment in the intercultural fifield: Axiology/value/praxis. Thousand Oaks, CA: Sage.

Clifford, J., \& Marcus, G. E. (1986). Writing culture: The poetics and politics of ethnography. Berkeley, CA: University of California Press. https://doi.org/10.1525/9780520946286

Cortazzi, M., \& Jin, L. (1999). Cultural mirriors: Materials and methods in the EFL classroom. In E. Hinkel (Ed.), Culture in second language teaching (pp. 196-219). Cambridge: Cambridge University Press.

Cunningsworth, A. (1995). Choosing your coursebook. Cambridge: Cambridge University Press.

Curdt-Christiansen, X. L., \& Weninger, C. (Eds.). (2015). Language, Ideology and Education: The Politics of Textbooks in Language Education. London, Routledge. https://doi.org/10.4324/9781315814223

Davidson, R., \& Liu, Y. C. (2020). Reaching the world outside: cultural representation and perceptions of global citizenship in Japanese elementary school English textbooks. Language, Culture and Curriculum, 33(1), 32-49. https://doi.org/10.1080/07908318.2018.1560460

Dendrinos, B. (1992). The EFL textbook and ideology. Athens, Greece: N. C. Grivas Publications.

Dirlik, A. (1996). Chinese history and the question of orientalism. History \& Theory, 35(4), 95-117. https://doi.org/10.2307/2505446

Duan, W. (2020). Evaluating the Representations of identities, linguistic and cultural elements in Chinese as a secong language textbooks used in China. Master. Dissertation, Yunnan University, Yunnan, China.

Han, H. (2011). "Love your China" and evangelise: Religion, nationalism, racism and immigrant settlement in Canada. Ethnography and Education, 6(1), 61-79. https://doi.org/10.1080/17457823.2011.553080

Harms, L. S. (1973). Intercultural communication. New York: Harper and Row.

Haynor, L. A., Apple, M. W., \& Christian-Smith, L. K. (1992). The politics of the textbook. Contemporary Sociology, 21(2), 229. https://doi.org/10.2307/2075462

Hinkel, E. (Ed.). (1999). Culture in second languages teaching and learning. Cambridge: Cambride University press.

Hong, H., \& He, X. (2015). Ideologies of monoculturalism in Confucius Institute textbooks: A corpus-based critical analysis. In X. Curdt-Christiansen \& C. Weninger (Eds.), Language, ideology and education: The politics of textbooks in language education (pp. 90-108). Routledge.

Hu, W. Z., \& Gao, Y. H. (1997). Foreign languages teaching and culture. Changsha: Hunan Education Press.

Ilieva, R. (2000). Exploring culture in texts designed for use in adult ESL classrooms. TESL Canada Journal, 17(2), 50-63. https://doi.org/10.18806/tesl.v17i2.889

Krippendorf, K. (2013). Content Analysis: An Introduction to Its Methodology. Los Angeles, CA: Sage

Lee, B. Y. (2010). Broadening the boundary of "Textbooks" for intercultural communication in Religious Education. Religious Education, 105(3), 249-252. https://doi.org/10.1080/00344081003771966

Li, J. (2020). Transnational migrant students between inclusive discourses and exclusionary practices. Multilingual, 1-19. https://doi.org/10.1515/multi-2019-0125

Li, J., \& Han, H. M. (2020). Learning to orient toward Myanmar: ethnic Chinese students from Myanmar at a university in China. Language, Culture and Curriculum, 39(2), 193-212. https://doi.org/10.1080/07908318.2020.1858095

Li, J., Dong, J., \& Duan, W. (2019). Identity options and cultural representations in English textbooks used in Cambodia. Asian Social Science, 15(11), 60-74. https://doi.org/10.5539/ass.v15n11p60

Li, J., Duan, W., Dong, J., \& Sharif. (2019). Identity construction and ideological reproduction of the secondary English language textbooks in Bangladesh. International Journal of Language and Linguistics, 7(6), 302-314. https://doi.org/10.11648/j.ij11.20190706.18 
Li, J., Ni Zh, J., \& Dong, J. (2020). The representations of Options and Cultural Elements in English Language Textbooks Used in Mayanmar. Journal of Linguistics and Literature, 4(2), 60-71. https://doi.org/10.12691/j11-4-2-3

Li, Y. M. (2017). On the issue of cross-cultural talents cultivation under globalization. Studies on Cultural Soft Power, 1(3), 5-12.

Liddicoat, A. J., \& Scarino, A. (2013). Intercultural languge teaching and learning. Malden, MA: Wiley-Blackwell. https://doi.org/10.1002/9781118482070

McClintock, A. (1995). Imperial Leather: Race, Gender and Sexuality in the Colonial Contest. New York: Routledge.

McDonough, S. (2002). Applied Linguistics in Language Education. London, Arnold.

Norton, B. (2000). Identity and language learning: Gender, ethnicity, and educational change. Harlow, UK: London.

Pan, Lin. (2015). English as a global language in China: Deconstructing the ideological discourses of English in language education. London: Springer. https://doi.org/10.1007/978-3-319-10392-1

Pennycook, A. (2002). English and the discourses of Colonialism. London: Routledge. (Original work published in 1998). https://doi.org/10.4324/9780203006344

Phillipson, R. (2008). The linguistic imperialism of neoliberal empire. Critical Inquiry in Language Studies, 5(1), 1-43. https://doi.org/10.1080/15427580701696886

Piller, I. (2017). Intercultural communication: A critical Introduction. Edinburgh University Press.

Rashidi, N., \& Safari, F. (2011). A Model for EFL Materials Development within the Framework of Critical Pedagogy (CP). English Language Teaching, 4(2), 250-259. https://doi.org/10.5539/elt.v4n2p250

Rich, A. L. (1974). Interracial communication. New York: Harper and Row.

Said, E. W. (1978). Orientalism: Western Conceptions of the Orient. London: Routledge \& Kegan Paul.

Said, E. W. (2003). Orientalism. London: Penguin.

Schein, L. (1997). Gender and internal Orientalism in China. Modern China, 23(1), 69-98. https://doi.org/10.1177/009770049702300103

Setyono, B., \& Widodo, H. P. (2019). The Representation of Multicultural Values in the Indonesian Ministry of Education and Culture-endorsed EFL Textbook: A Critical Discourse Analysis. Intercultural Education, 30, 383-397. https://doi.org/10.1080/14675986.2019.1548102

Shardakova, M., \& Pavlenko, A. (2004). Identity options in Russian textbooks. Journal of Language, Identity and Education, 3(1), 25-46. https://doi.org/10.1207/s15327701jlie0301_2

Shin, J., Eslami, Z. R., \& Chen, W. C. (2011). Presentation of local and international culture in current international English-language teaching textbooks. Language, Culture and Curriculum, 24(3), 253-268. https://doi.org/10.1080/07908318.2011.614694

Song, B. B. (2019). Exploring the cultural content in Chinese ELT Textbooks from Intercultural Perspectives. The Journal of Asia TEFL, 16(1), 267-278. https://doi.org/10.18823/asiatefl.2019.16.1.17.267

Suo, G. F. (Eds.). (2013). An analytical evaluation of intercultural communication textbooks published in China. Proceedings of the 10th Chinese International Symposium on Intercultural Communication, 993-1011.

Suo, G. F., Weng, L, P., \& Gu, L. X. (2015). An analytical evaluation of 30 years of intercultural communication textbooks in China (1985-2014). Foreign Language World, 168(3), 89-96.

Tajeddin, Z., \& Teimournezhad, S. (2015). Exploring the hidden agenda in the representation of culture in international and localised ELT textbooks. The Language Learning Journal, 43(2), 180-193. https://doi.org/10.1080/09571736.2013.869942

Tajima, M. (2011). Ideological messages embedded in an EFL textbook. Retrieved from file:///Users/abdullahaljumiah/Downloads/jalt2010proc-34.pdf

Taki, S. (2008). International and local curricula: The question of ideology. Language Teaching Research, 12(1), 127-142. https://doi.org/10.1177/1362168807084503 
van Dijk, T. A. (1992). Discourse and the denial of racism. Discourse and Society, 3(1), 87-118. https://doi.org/10.1177/0957926592003001005

Yan, M. (2015). English Intercultural Communication Course in College. Beijing: Tsinghua University Press.

Zheng, X. M., \& Davison, C. (2008). Changing pedagogy: Analysing ELT teachers in China. London: Continuum. https://doi.org/10.5040/9781350091306

\section{Copyrights}

Copyright for this article is retained by the author(s), with first publication rights granted to the journal.

This is an open-access article distributed under the terms and conditions of the Creative Commons Attribution license (http://creativecommons.org/licenses/by/4.0/). 